\title{
Estimating The Ability of Lanceleaf Arrowhead (Sagittaria lancifolia) in Phytoremediation of Heavy Metal Copper (Cu)
}

\author{
(Pendugaan Kemampuan Tanaman Daun Tombak (Sagittaria lancifolia) dalam \\ Fitoremediasi Logam Berat Tembaga (Cu)) \\ Alfin Fatwa Mei Afifudin ${ }^{1 *}$, Rony Irawanto ${ }^{2}$ \\ ${ }^{1}$ Jurusan Biologi, Fakultas Sains dan Teknologi, Universitas Islam Negeri Sunan Ampel Surabaya \\ ${ }^{2}$ Pusat Penelitian Konservasi Tumbuban Kebun Raya, Lembaga Ilmu Pengetabuan Indonesia (LIPI)
}

\section{ABSTRACT}

One of Indonesia's strategies to improve the quality of its economy as a developing country is to boost industrial activity. However, the existence of industry has a detrimental consequence, one of which is heavy metal copper pollution (Cu). Phytoremediation is one of the ecologically acceptable pollutant treatment methods. Phytoremediation approaches using Sagittaria lancifolia plants are thought to be capable of overcoming heavy metal $\mathrm{Cu}$ contamination in the environment. This research is a preliminary study into the limitations of the Sagittaria lancifolia plant's capacity to absorb heavy metal Cu. This study employed an experimental technique, which was carried out between March 26 and April 7, 2021, in the Purwodadi Botanic Garden's Greenhouse, with four concentration variations, namely $0 \mathrm{mg} / \mathrm{L}, 1 \mathrm{mg} / \mathrm{L}, 3 \mathrm{mg} / \mathrm{L}$, and $5 \mathrm{mg} / \mathrm{L}$. According to the result of this research, the plant Sagittaria lancifolia may remediate heavy metal $\mathrm{Cu}$ at a maximum concentration of $5 \mathrm{mg} / \mathrm{L}$. This is due to the fact that at this concentration, the Sagittaria lancifolia plant presents indications of death, particularly severe chlorosis and necrosis.

Keywords: Sagittaria lancifolia, Phytoremediation, Range Finding Test, Cuprum.

$\left.{ }^{*}\right)$ Corresponding author:

Alfin Fatwa Mei Afifudin

E-mail: alfianfatwa@gmail.com

\section{PENDAHULUAN}

Salah satu upaya yang dilakukan oleh negara berkembang seperti Indonesia agar bisa meningkatkan perekonomian negara ialah dengan memperbanyak industri. Diantara kegiatan industri yang dilakukan di Indonesia ialah industri tambang, pupuk kimia, tekstil, dan elektroplating. Adanya industri juga turut menyumbang limbah berupa zat pencemar yang apabila dibiarkan, akan mencemari ekosistem dan membahayakan makhluk hidup yang tinggal di lingkungan tersebut. Salah satu ekosistem yang kerap kali tercemar ialah ekosistem perairan. Sedangkan air sendiri merupakan suatu sumber daya alam yang teramat penting dalam kehidupan hamper semua organisme [1].
Diantara pencemar yang umun mencemari peraira ialah logam berat seperti tembaga $(\mathrm{Cu})$, kromium $(\mathrm{Cr})$, timbal $(\mathrm{Pb})$, cadmium $(\mathrm{Cd})$, dan nikel (Ni) [2]. Namun penelitian yang dilakukan Yunasfi dan Singh [3] melaporkan bahwa ditemukan kandungan logam $\mathrm{Cu}$ pada bakau Avicennia marina dan Rhizophora mucranata di prairan Belawan dengan kandungan $\mathrm{Cu}$ sebesar $358.707 \mathrm{mg} / \mathrm{L}$, selain itu Sekarwati [4] juga memaparkan bahwa di Kotagede juga telah tercemar tembaga $(\mathrm{Cu})$ dengan konsentrasi $84,9 \mathrm{mg} / \mathrm{L}$, yang mana telah melampaui baku mutu tembaga $(\mathrm{Cu})$ dalam perairan, yakni $0,6 \mathrm{mg} / \mathrm{L}$. Berdasarkan beberapa penelitian tersebut, diketahui logam $\mathrm{Cu}$ merupakan salah satu jenis logam berat yang banyak mencemari lingkungan terutama perairan. Adanya pencemaran $\mathrm{Cu}$ dalam perairan umumnya dihasilkan oleh limbah dari industry tekstil, manufaktur, dan pelapisan logam [4] 
Lebih lanjut, proses bioakumulasi kedalam tubuh biasanya terjadi melalui rantai makanan [5]. Jika kadar logam berat yang melebihi ambang batas dan tersimpan dalam waktu yang lama dalam tubuh makhluk hidup dapat menyebabkan gangguan fisologis dan metabolisme tubuh suatu makhluk hidup [6]. Oleh karena itu, diperlukan solusi dalam mengatasi pencemaran logam $\mathrm{Cu}$ di lingkungan, terutama pada ekosistem perairan.

Salah satu cara dalam menanggulangi masalah pencemaran air ialah dengan cara fitoremediasi. Fitoremediasi ialah suatu teknik yang bertujuan mengambalikan kualitas suatu lingkungan yang tercemar dengan menggunakan tumbuhan [7]. Teknik ini dinilai cukup efektif, ekonomis, dan juga ramah lingkungan, sehingga mampu untuk dijadikan solusi dalam mengembalikan fungsi lingkungan yang tercemar [8]. Telah banyak penelitian dengan berbagai jenis tanaman yang diaplikasikan dalam upaya fitoremediasi, salah satunya ialah tanaman daun tombak (Sagittaria lancifolia). Diantara penelitan tersebut dilakukan oleh Serang [9] dengan menggunakan tanaman ini untuk fitoremediasi logam berat Cr. Adapun hasilnya ialah tanaman daun tombak mampu menurunkan kadar Cr sebesar 80,6\% atau 4, 032 ppm. Selain itu, Kustiyaningsih [10] juga melaporkan bahwa tanaman daun tombak mampu menurukan kadar detergen LAS sebesar 81,53\%. Selain itu, Sagittaria lancifolia memiliki beberapa keunggulan, di antaranya ialah tanaman ini tidak dikonsumsi, bisa hidup di air tawar maupun payau, banyak ditemukan di alam terutama sekitar sungai, dan juga pemanfaatan tanaman ini sampai saat ini hanya sebatas untuk tanaman hias saja [11]. Oleh karena itu, tanaman daun tombak (Sagittaria lancifolia) dirasa mampu untuk meremediasi logam berat tembaga $(\mathrm{Cu})$ dalam perairan.

Penelitian fitoremediasi umumnya dilakukan dengan beberapa tahap, diantaranya diawali dengan Range finding test atau biasa disebut uji pendahuluan. Uji ini perlu dilakukan untuk menentukan nilai konsentrasi dari zat pencemar yang akan digunakan dalam penelitian fitoremediasi [9]. Oleh karena itu, penelitian ini merupakan penelitian awal dengan tujuan untuk mengetahui nilai konsentrasi logam berat tembaga $(\mathrm{Cu})$ yang akan digunakan dalam fitoremediasi dengan menggunakan tanaman daun tombak (Sagittaria lancifolia).

\section{METODE PENELITIAN}

Penelitian ini merupakan penelitian eksperimental yang dilakukan di rumah kaca Balai Konservasi Tumbuhan Kebun Raya Purwodadi - LIPI pada tanggal 26 Maret 2021 hingga 07 April 2021. Penelitian ini dilakukan dengan empat perlakuan berdasarkan variasi konsentrasinya, yakni $0 \mathrm{mg} / \mathrm{L}, 1$ $\mathrm{mg} / \mathrm{L}, 3 \mathrm{mg} / \mathrm{L}$, dan $5 \mathrm{mg} / \mathrm{L}$. Alat-alat yang digunakan pada penelitian ini ialah botol vial, wadah 2 liter, $\mathrm{pH}$ meter, TDS meter, thermometer, alat tulis, glas ukur, dan pengaduk. Sedangkan bahan yang digunakan ialah air suling, larutan larutan $\mathrm{Cu}\left(\mathrm{NO}_{3}\right)_{2}$, aquades, dan tanaman daun tombak (Sagittaria lancifolia). Parameter yang diamati adalah nilai $\mathrm{pH}$, TDS, suhu, dan perubahan morfologi tumbuhan. Analisis dilakukan dengan deskriptif kualitatif, yakni dengan menguraikan data dan fakta secara berurutan.

Tahapan penelitian diawali dengan aklimatisasi, sembari tanaman diaklumatisasi dilakukan pembuatan larutan kerja. Kemudian setelah aklimatisasi dilanjutkan dengan treatment Range Finding Test (RFT).

\section{Aklimatisasi}

Aklimatisasi dilakukan dengan mengambil perbanyakan tanaman Sagittaria lancifolia dengan tinggi $\pm 45 \mathrm{~cm}$ di kolam perbanyakan dan memindahkannya di rumah kaca. Setelah itu, tanaman dibiarkan pada wadah yang berisikan air selama 2 minggu hingga muncul tunas dan akar yang baru. Aklimatisati tanaman bertujuan agar tanaman mampu beradaptasi dengan lingkungan yang baru sehingga akan terbentuk tanaman yang seragam.

\section{Pembuatan Larutan Kerja}

Pembuatan larutan kerja yang dibutuhkan berdasarkan variasi konsentrasi dalam penelitian, yakni $0 \mathrm{mg} / \mathrm{L}, 1 \mathrm{mg} . \mathrm{L}, 3 \mathrm{mg} / \mathrm{L}$, dan $5 \mathrm{mg} / \mathrm{L}$. Adapun pembuatannya dilakukan dengan menggunakan rumus pengenceran. Larutan induk yang dipakai ialah $\mathrm{Cu}\left(\mathrm{NO}_{3}\right)_{2}$ konsentrasi 30 ppm. Sedangkan untuk rumus yang dipakai ialah:

$$
\mathrm{M} 1 \times \mathrm{V} 1=\mathrm{M} 2 \times \mathrm{V} 2
$$

Keterangan:

M1 : Konsentrasi larutan awal

M2 : Konsentrasi larutan yang diinginkan

V1 : Volume air awal

V2 : Volume air setelah pengenceran 


\section{Pelaksanaan Penelitian}

Penelitian ini dilakukan dengan tujuan mengetahui konsentrasi maksimal logam berat $\mathrm{Cu}$ bagi tanaman untuk bisa hidup atau biasa dinamakan Range Finding Test (RFT). Setelah tanaman diaklimatisasi kemudian diletakkan didalam wadah bak yang berisi $2000 \mathrm{~mL}$ air yang sebelumnya telah ditambahkan logam berat $\mathrm{Cu}$ sesuai variasi konsentrasi yang digunakan. Selanjutnya tanaman dan air diamati secara berkala selama 2 minggu mengenai parameter-parameter yang telah ditentukan dalam penelitian.

\section{HASIL DAN PEMBAHASAN}

Penelitian ini merupakan penelitian pendahuluan untuk mengetahui kemampuan tanaman daun tombak (Sagittaria lancifolia) dalam menghadapi tekanan pencemar berupa logam berat tembaga $(\mathrm{Cu})$. Terdapat 4 variasi konsentrasi yang digunakan dalam penelitian, yakni $0 \mathrm{mg} / \mathrm{L}, 1 \mathrm{mg} / \mathrm{L}, 3 \mathrm{mg} / \mathrm{L}$, and $5 \mathrm{mg} / \mathrm{L}$. variasikonsentrasi ini didasarkan oleh [9] yang mengungkapkan bahwa Sagittaria lancifolia mampu bertahan pada cekaman logam kromium (Cr) dengan konsentrasi maksimum $5 \mathrm{mg} / \mathrm{L}$. Beberapa parameter pengukuran yang digunakan ialah $\mathrm{pH}$, TDS, dan suhu air. Hal ini karena parameter-parameter tersebut memiliki pengaruh dengan kemampuan tanaman daun tombak dalam upaya fitoremediasi [4], [10], [12]. Lebih lanjut mengenai kemampuan awal Sagittaria lancifolia dalam fitoremediasi logam berat tembaga $(\mathrm{Cu})$ ialah sebagai berikut.

\section{Nilai pH}

\begin{tabular}{cccccc}
\multicolumn{5}{c}{ Tabel 1. Nilai pH } \\
\hline \multirow{2}{*}{ No } & \multirow{2}{*}{ Waktu } & V Variasi Konsentrasi \\
& & 1 ppm & 3 ppm & 5 ppm \\
\hline 1 & Hari ke-1 & 7,4 & 6,8 & 5,8 & 5,5 \\
2 & Hari ke-4 & 7,6 & 7,3 & 6,5 & 6 \\
3 & Hari ke-6 & 7,8 & 7,7 & 6,7 & 6,1 \\
4 & Hari ke-8 & 7,7 & 7,6 & 7,1 & 6,2 \\
5 & Hari ke-11 & 8,1 & 8 & 7,7 & 6,5 \\
6 & Hari ke-14 & 8,3 & 8,1 & 7,7 & 6,7 \\
\hline
\end{tabular}

Pengukuran $\mathrm{pH}$ dilakukan dengan tujuan untuk mengetahui kondisi nilai keasaman pada media pertumbuhan tanaman. Terlihat pada Tabel 1 bahwa pada pengukuran awal, nilai $\mathrm{pH}$ pada masing-masing variasi berkisar antara 5,5 pada konsentrasi 5 ppm sampai 7,4 pada konsentrasi 0 ppm. Hal ini menunjukkan bahwa semakin tinggi konsentrasi logam $\mathrm{Cu}$ dalam air, maka semakin rendah nilai $\mathrm{pH}$ nya. Penyebabnya ialah karena semakin tinggi kadar $\mathrm{Cu}$ dalam air, maka semakin tinggi pula padatan tersuspensi yang terkandung dalam air tersebut, sehingga akan menurunkan nilai $\mathrm{pH}$ dalam air [4]. Kemudian dari pengamatan yang telah dilakukan, dapat diketahui bahwa nilai $\mathrm{pH}$ mengalami kenaikan antara $\mathrm{H}+1$ pemberian tananaman dan $\mathrm{H}+14$ pemberian tanaman, atau bisa dikatakan nilai $\mathrm{pH}$ semakin lama semakin meningkat, hal ini dikarenakan menurut Ayres [13] peningkatan nilai $\mathrm{pH}$ larutan dari yang semula asam menjadi basa dapet menurunkan konsentrasi logam berat dalam larutan tersebut.

Perubahan nilai $\mathrm{pH}$ juga dapat disebabkan oleh adanya proses fotosintesis dan respirasi oleh tanaman atau mikroorganisme dalam air [14]. Karena pada reaksi fotosintesis akan mengikat banyak senyawa CO2 sehingga akan meningkatkan $\mathrm{pH}$ dala air. Berdasarkan Tabel 1, rata-rata nilai $\mathrm{pH}$ berkisar antara 6,1 - 7,8. Nilai in masih sesuai dengan Peraturan KLHK No. 68 Tahun 2016 yakni baku mutu pH air berada berkisar 6 sampai 9. Selain itu, menurut Suryan [12] jika pada suatu perairan memiliki nilai $\mathrm{pH}$ rendah, maka logam berat pada perairan tersebut tinggi, begitupun jika $\mathrm{pH}$ perairan tinggi, maka logam beratnya rendah. Berdasarkan pernyataan tersebut dapat diketahui bahwa pada penelitian ini terjadi pengurangan kadar logam berat $\mathrm{Cu}$ dalam air oleh tanaman daun tombak, ditandai dengan naiknya $\mathrm{pH}$ pada masing-masing perlakuan.

\section{Nilai TDS}

Tabel 2. Nilai TDS

\begin{tabular}{cccccc}
\hline \multirow{2}{*}{ No } & \multirow{2}{*}{ Waktu } & \multicolumn{4}{c}{ Variasi Konsentrasi } \\
& & 0 ppm & 1 ppm & 3 ppm & 5 ppm \\
\hline 1 & Hari ke-1 & 180 & 192 & 248 & 344 \\
2 & Hari ke-4 & 199 & 235 & 256 & 348 \\
3 & Hari ke-6 & 205 & 173 & 227 & 380 \\
4 & Hari ke-8 & 182 & 186 & 233 & 316 \\
5 & Hari ke-11 & 209 & 215 & 289 & 364 \\
6 & Hari ke-14 & 207 & 213 & 293 & 367 \\
& Ket & $\mathbf{2 7}$ & $\mathbf{2 1}$ & $\mathbf{4 5}$ & $\mathbf{2 3}$ \\
\hline
\end{tabular}

Pada Tabel 2 merupakan hasil dari pengukuran nilai konsentrasi TDS. Total Disolved Solid (TDS) atau merupakan padatan yang memiliki ukuran lebih kecil dari padatan tersuspensi. Dalam kadar yang normal, TDS tidak memiliki sifat toksik, namun ada kadar yang tinggi TDS dapat menyebabkan pencemaran karena 
meningkatkan kekeruhan dalam air [10]. Berdasarkan Tabel 2 dapat diketahui bahwa semakin tinggi kadar $\mathrm{Cu}$ dalam air, maka semakin tinggi pula kadar TDSnya. Hal ini karena semakin tinggi kadar $\mathrm{Cu}$ dalam air, semakin tinggi pula padatan tersuspensi yang terkandung dalam air tersebut [4]. Pada Tabel 2 dapat diketahui bahwa semakin lama waktu pengamatan, nilai TDS dalam air mengalami peningkatan pada setiap variasi konsentrasi, namun peningkatan TDS tertinggi ialah pada perlakuan dengan konsentrasi $\mathrm{Cu}$ 3 ppm. Adanya peningkatan TDS dapat disebabkan karena banyaknya bahan organik pada media yang dihasilkan oleh sisa-sisa jaringan atau organ tumbuhan yang mengalami kematian [15].

\section{Nilai Temperatur}

Tabel 3. Temperatur air $\left({ }^{\circ} \mathrm{C}\right)$

\begin{tabular}{cccccc}
\hline \multirow{2}{*}{ No } & \multirow{2}{*}{ Waktu } & \multicolumn{4}{c}{ Variasi Konsentrasi } \\
& & 0 ppm & 1 ppm & 3 ppm & 5 ppm \\
\hline 1 & Hari ke-1 & 22,5 & 22,6 & 22,6 & 22,7 \\
2 & Hari ke-4 & 23,5 & 27,5 & 23,4 & 23,5 \\
3 & Hari ke-6 & 25,7 & 25,7 & 25,5 & 25,4 \\
4 & Hari ke-8 & 26,2 & 26,5 & 26,8 & 26,9 \\
5 & Hari ke-11 & 23,6 & 23 & 23,8 & 23 \\
6 & Hari ke-14 & 21,8 & 21 & 22,2 & 22,5 \\
& Rata-rata & $\mathbf{2 3 , 8}$ & $\mathbf{2 4 , 3}$ & $\mathbf{2 4 , 0 5}$ & $\mathbf{2 4}$ \\
\hline
\end{tabular}

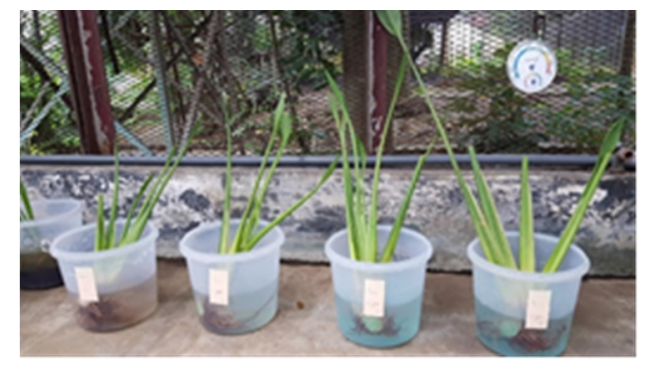

Gambar 1. Tanaman hari ke-1

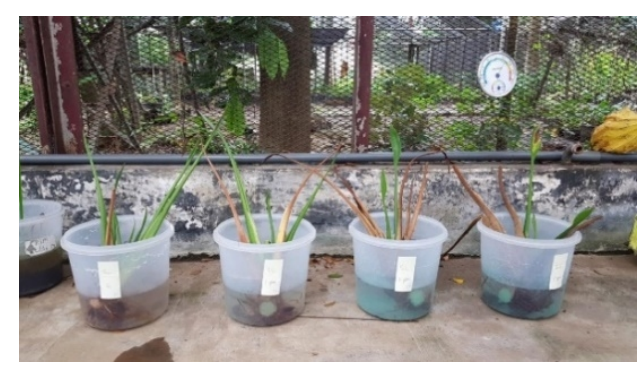

Gambar 2. Tanaman hari ke-14

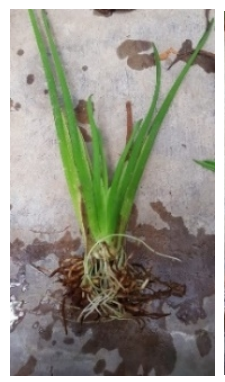

(a)

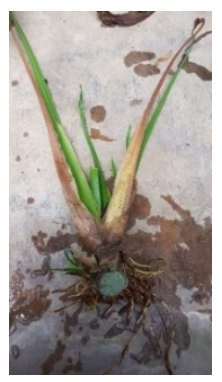

(b)

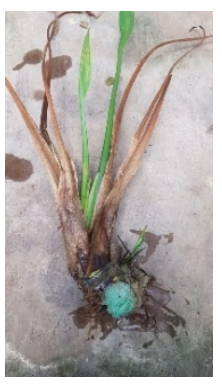

(c)

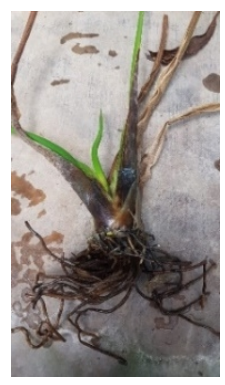

(d)

Gambar 3. Kondisi tanaman hari ke-14. (a) kontrol; (b) 1 ppm; (c) 3 ppm; (d) 5 ppm 
Pertumbuhan diamati pada beberapa parameter, diantaranya ialah perpanjangan dan pertambahan akar, jumlah daun, dan jumlah pertambahan anakan. Gambar 1 menunjukkan kondisi awal tanaman daun tombak. Pada gambar tersebut dapat diketahui bahwa kondisi tanaman pada hari ke-1 sangat baik, hal ini ditandai dengan daun yang segar, tegak, dan berwarna hijau cerah. Sedangkan pada Gambar 2 menunjukkan kondisi tanaman pada hari ke-14. Kondisi tanaman pada semua perlakuan kecuali pada perlakuan kontrol menunjukkan terdapat beberapa daun yang layu. Adapun secara jelas mengenai kondisi tanaman pada masing-masing perlakuan dapat dilihat pada Gambar 3. Pada perlakuan kontrol, tanaman terlihat dalam keadaan segar baik itu pada daun, batang, maupun akarnya. Bahkan terlihat munculnya tunas daun dan akar baru yang cukup banyak. Hal ini dikarenakan tanaman tidak mendapatkan cekaman dari logam berat sehingga tanaman bisa melakukan proses fotosintesis dan metabolismenya dengan maksimal.

Pertumbuhan tanaman pada penelitian ini dipengaruhi oleh adanya interaksi antara tanaman daun tombak dan kosentrasi logam Cu. Kondisi perakaran pada kelompok treatment menunjukkan kondisi yang tidak baik, terlihat akar mengalami kerusakan dan tidak mengalami penambahan atau pertumbuhan akar (Gambar 3b, c, d). Kondisi terburuk dijumpai pada akar tanaman pada konsentrasi 5 ppm. Menurun dan rusaknya akan dapat disebabkan oleh hambatan penyerapan nutrisi dan gangguan metabolisme dalam sel [18], dan akar merupakan organ yang langsung berinteraksi dengan cekaman dan transportasi air serta mineral [19]. Selain itu, kondisi daun pada kelompok treatment juga mengalami kerusakan berupa layu dan klorosis (Gambar 3b, c, d). Hal ini terjadi karena tanaman menyerap logam berat secara berlebih dan menyebabkan terganggunya penyerapan magnesium dan zat besi sehingga proses sinteris klorofil menjadi terhambat [20] Lebih lanjut, Maksymiec [21] memaparkan pada konsentrasi tinggi, logam $\mathrm{Cu}$ akan menghambat penyerapan nutrisi sehingga nutrisi tidak tertranslokasi sampai bagian shoot tanaman.

Berdasarkan kondisi morfologi tanaman daun tombak (Sagittaria lancifolia) setelah terpapar logam $\mathrm{Cu}$ selama 14 hari (Gambar 2), terlihat tanaman mengalami gejala kematian. Sehingga dapat diketahui kemampuan maksimal tanaman tersebut dalam mentolelir cekaman logam berat tembaga $(\mathrm{Cu})$ ialah pada konsentrasi $5 \mathrm{mg} / \mathrm{L}$.

\section{KESIMPULAN}

Tumbuhan daun tombak (Sagittaria lancifolia) mampu untuk dijadikan sebagai tumbuhan fitoremediasi logam berat tembaga $(\mathrm{Cu})$. Adapun konsentrasi maksimum logam berat tembaga $(\mathrm{Cu})$ yang dapat ditolerir oleh tumbuhan daun tombak (Sagittaria lancifolia) ialah pada konsentrasi $5 \mathrm{mg} / \mathrm{L}$. karena pada konsentrasi ini tumbuhan mulai menunjukkan respon layu pada tajuk dan kerusakan pada akar.

\section{UCAPAN TERIMA KASIH}

Terima kasih penulis ucapkan kepada kepala Balai Konservasi Tumbuhan (BKT) Kebun Raya Purwodadi - LIPI yang telah meberikan izin serta memfasilitasi penulis dalam melakukan penelitian ini. Serta kepada pembimbing lapangan penulis yang banyak membantu, membimbing, dan mengarahkan penulis dalam penelitian dan penyusunan artikel ini.

\section{DAFTAR PUSTAKA}

[1] S. . Fitria, "Potensi Tanaman Genjer (Limnocharis Flava) Untuk Mengurangi Kadar Logam Berat $(\mathrm{Pb}$ Dan Cu) Serta Radionuklida Dengan Metode Fitoremediasi," Universitas Brawijaya, Malang, 2014.

[2] S. A. Zubayr, "Analisis Status Pencemaran Logam Berat di Wilayah Pesisir (Studi Kasus Pembuangan Limbah Cair dan Tailing Padat/Slag Pertambangan Nikel Pomalaa)," IPB (Bogor Agricultural University), Bogor, 2009.

[3] D. Yunasfi and K. P. Singh, "The heavy metal of cuprum $(\mathrm{Cu})$ and lead $(\mathrm{Pb})$ content in Avicennia marina and Rhizophora mucranata The heavy metal of cuprum $(\mathrm{Cu})$ and lead $(\mathrm{Pb})$ content in Avicennia marina and Rhizophora mucranata," IOP Conf. Ser. Earth Environ. Sci., vol. 374, no. 1, Nov. 2019.

[4] N. Sekarwati, "Dampak Logam Berat Cu (Tembaga) dan Ag (Perak) pada Limbah Cair Industri Perak Terhadap Kualitas Air Sumur dan Kesehatan Masyarakat serta Upaya Pengendaliannya di Kota Gede Yogyakarta," UNS Sebelas Maret, Surakarta, 2014.

[5] M. Zainuri, S. Sudrajat, and E. S. Siboro, "Kadar Logam Berat $\mathrm{Pb}$ pada Ikan Beronang (Siganus sp), 
Lamun, Sedimen dan Air di Wilayah Pesisir Kota Bontang-Kalimantan Timur," J. Kelaut. Indones. J. Mar. Sci. Technol., vol. 4, no. 2, pp. 102-118, Oct. 2011.

[6] H. H. Rosihan, Logam Berat Sekitar Manusia. Banjarmasin: Lambung Mangkurat Press, 2017.

[7] S. B. Rondonuwu, "Fitoremediasi Limbah Merkuri Menggunakan Tanaman Dan Sistem Reaktor," J. Ilm. Sains, vol. 14, no. 1, pp. 52-59, 2014.

[8] L. Sidauruk and P. Sipayung, "Fitoremidiasi Lahan Tercemar di Kawasan Industri Medan dengan Tanaman Hias," Pertan. Trop., vol. 2, no. 2, pp. 178-186, 2015.

[9] L. Serang, E Handayanto, and R Rindyastuti, "Fitoremediasi Air Tercemar Logam Kromium Dengan Menggunakan Sagittaria lancifolia dan Pistia stratiotes Serta Pengaruhnya Terhadap Pertumbuhan Kangkung Darat," J. tanah dan Sumberd. laban, vol. 5, no. 1, pp. 739-746, 2018.

[10] E. Kustiyaningsih and R. Irawanto, "Pengukuran Total Dissolved Solid (Tds) Dalam Fitoremediasi Deterjen Dengan Tumbuhan," J. Tanah dan Sumberd. Laban, vol. 7, no. 1, pp. 143-148, 2020.

[11] E. Dewi, L. Andriana, and R Irawanto, "Phenology Study of Aquatic Plants (Sagittaria lancifolia and Echinodorus radicans) in Purwodadi Botanic Garden," in Prosiding, 2018, p. 114.

[12] M. Suryan, N. Nursal, and E. Febrita, "Kandungan Logam Berat Timbal $(\mathrm{Pb})$ dan Kadmium (Cd) pada Anadara Granosa di Pantai Nongsa Kota Batam untuk Penyusunan Lembar Tugas Siswa pada," J. online mabsiswa.

[13] D. Ayres, A. Davis, P. G.-E. R. Centre, and U. 1994, "Removing heavy metals from wastewater," Eng. Res. Cent. Rep., 1994.

[14] Suryadi, A. Isna, and U. Kadaria, "Uji Tanaman Coontail (Ceratophyllum Demersum) Sebagai Agen Fitoremediasi Limbah Cair Kopi," J. Teknol. Lingkung. lahan baasah, vol. 5, no. 1 .

[15] E. Kustiyaningsih and R Irawanto, "Pengukuran Total Dissolved Solid (Tds) Dalam Fitoremediasi Deterjen Dengan Tumbuhan Sagittaria Lancifolia," J. Tanah dan Sumberd. Lahan, vol. 7, no. 1, pp. 143-148, 2020.

[16] S. Ikawati, A. Zulfikar, and D. A. Umrah, "Efektivitas Dan Efisiensi Fitoremediasi Pada Deterjen Dengan Menggunakan Tanaman Genjer (Limnocharis flava) Fitoremediation Effectivity and Efficiency of," J. Umr.

[17] N. Hendrasarie and Y. A. Dieta, "Kemampuan Adsorpsi Pb Dari Limbah Industri Oleh Tumbuhan Kayu Ambang (Lemna Minor), Kayu Apu (Pistia Stratiotes), Dan Eceng," J. Envirotek, vol. 1, no. 1.

[18] L. Taiz and E. Zeiger, Plant Physiology. Sinauer Associates. Massachetts, USA.: Sunderland, 2010.
[19] G. Ouzounidou, M. Čiamporová, M. Moustakas, and S. Karataglis, "Responses of maize (Zea mays L.) plants to copper stress-I. Growth, mineral content and ultrastructure of roots," Environ. Exp. Bot., vol. 35, no. 2, pp. 167-176, Apr. 1995.

[20] Y. Novita and T. P. Bio, "Penyerapan logam timbal (Pb) dan kadar klorofil Elodea canadensis pada limbah cair pabrik pulp dan kertas," Lentera Bio, vol. 1, no. 1, pp. $1-8$.

[21] W. Maksymiec, "Effect of copper on cellular processes in higher plants," Photosynthetica, vol. 34, no. 3, pp. 321342, Jan. 1998. 